\title{
Advanced Clear Cell Sarcoma of Soft Tissue
}

National Cancer Institute

\section{Source}

National Cancer Institute. Advanced Clear Cell Sarcoma of Soft Tissue. NCI Thesaurus. Code C161586.

A clear cell sarcoma of soft tissue that has spread extensively to other anatomic sites or is no longer responding to treatment. 